und Cygany in Südostgalizien; an allen genannten Standorten ziemlich zahlreich.

Bemerkungen: Von den systematisch nächst verwandten Arten unterscheidet sich $G$. polonicum $\mathrm{m}$. folgendermassen: Von $G$. mollugo L. durch längere und allmälig zugespitzte, aufrecht oder fast wagrecht abstehende Blätter, steif aufrechten Stengel, durch unter einem spitzen Winkel abstehende Aeste der Inflorescenz und endlich durch dünnere, stets aufrecht abstehende Blüthenstielchen. Von $G$. aristatum L. durch höheren Wuchs, längere Internodien, relativ kürzere, glänzende Blätter, viel reichlicheren Blüthenstand und etwas dickere Blüthenstielchen. Von $G$. Schultesii Vest. durch relativ schmälere und glänzende (niemals bereifte) Blätter. Von $G$. pseudoaristatum Schur ( $G$. asperuliflorum Borb.) durch breitere, glänzende Blätter, viel reichlicheren Blüthenstand, sowie durch k ürzere und dickere Blüthenstielchen. Von $G$. erectum auct. austr. endlich durch höheren Wuchs, längere und anders gostaltete Blätter, viel breitere Inflorescenz und dünnere Blüthenstielchen. Hier sei noch bemerkt, dass ich in Bilcze eine f. pilosa $\operatorname{des} G$. polonicum $\mathrm{m}$. mit behaarten Stengeln und Blättern in einigen wenigen Exemplaren unter der Grundform beobachtet habe.

In der Diagnose der Poa polonica m. ist zu berichtigen:

6. Zeile von oben, statt: „3 $3 \mathrm{Mm}$. lang", soll es heissen: „3 Mm. breit". 12. Zeile ron unten, statt:" "auch hung.", soll es heissen: "auct. hung.".

\title{
Ueber Symbiose von Bacterien (in Zoogloea-Form) mit der Alge Glacacapsa polydermatica Ktz.
}

Vorläufige Mittheilung:

\section{Von Prof. Anton Tomaschek.}

Im Monate April fand ich in einem halb unterirdisch angelegten Warmhause (Augarten) in einer Abtheilung desselben, welche hauptsächlich der Vermehrung gewidmet wird, die Wände stellenweise mit einem schleimig-gelatinösen Ueberzug bekleidet; die Farbe desselben war schmutzig violett oder chocoladebraun, die Consistenz die des Kleisters und die Höhe der Schichte betrug stellenweise bis $2 \mathrm{Mm}$. Ins Wasser gebracht, fiel die Masse ondlich flockig auseinander und senkte sich zu Boden.

Die Bedingungen, unter welchen diese Bildung zu Stande kam, lassen sich aus der Beschaffenheit des Fundortes ableiten: feuchte ruhige Luft, hohe Temperatur, wechselnde geringe Beleuchtung förderten die Entwickelung. Beachtenswerth ist es ferner, dass die Hauptplätze dieses Vorkommens sich besonders in der Nähe des Einganges befanden, was insbesondere mit dem Einströmen von frischer Luft in Zusammenhang gebracht werden muss. 
Die mikroskopische Untersuchung erwies, dass die gelatinöse Grundmasse hauptsächlich aus einem Stäbchenbacterium besteht, welches ich am liebsten mit Bacillus Megatherium vergleichen möchte. ${ }^{1}$ ) Jedes dieser meist etwas gekrümmten Stäbchen ist von einem im Umrisse ovalen glänzend durchsichtigen Hof umgeben. Die gelatinöse Beschaffenheit der Gesammtmasse ist somit durch diese eigenthümliche Hülle, welche die Breite der Stäbchen hat, bedingt, da die letztere sammt ihrem Hof sich in allen Richtungen eng aneinander schmiegen. Meist wird diese aus freiliegenden Stäbchenbacterien gebildete Grundmasse von einem feinen Geflechte dünner Bacterienfäden durchzogen, welche jedoch durch Einwirkung von Jodtinctur sich in kurze Gliedmassen zerlegen.

In dieser bacteriösen Grundmasse sind nun überall grössere oder kleinere Inseln von Gloeocapsa polydermatica eingebettet, welche auch dann in Theilung begriffen zu sein scheinen, wenn stellenweise die Zellen ihre blaugraue Färbung in eine trübgelbgrüne verändert haben oder gänzlich farblos geworden sind..$^{2}$ )

Nur an manchen Stellen, insbesondere am Grunde der gelatinösen Bacterienmasse oder am Rande derselben häufen sich die Gloeocapsa-Colonien in solcher Menge an, dass sie die Bacterien grösstentheils verdrängen. In letzterem Falle behalten die Zellen der Gloeocapsa ihre ursprüngliche blaugrüne Färbung bei, während sie, wenn sie am Grunde auftreten oder zerstreut in kleineren Colonien der Zoogloeamasse einlagern, sich verfärben oder verblassen. Kleinere Colonien der Alge sind übrigens überall in der Zoogloea gleichmässig vertheilt und jede noch so kleine Partie der letzteren unter das Mikroskop gebracht, wird einzelne kleinere Algencolonien anfweisen. Es muss hier auch noch Erwähnung finden, dass hie und da mitten aus der Zoogloeamasse einzelne Moospflänzchen frei hervortreten und daher auch hie und da in der schleimigen Masse Moosprotonemata oder sogar Farren-Prothalien sich vorfinden.

Diese Association der Zoogloea mit den Algen, welche an die Vereinigung der flechtenbildenden Pilze mit Algen, beziehungsweise an die Collemaceen erinnern, ist offenbar keine zufällige blosse Wohnungsgemeinschaft. Dieses Zusammenleben ist vielmehr horvorgerufen durch das Sauerstoffbedürfniss des Bacteriums. Zu dieser Anschauung werde ich hingedrängt, wonn ich erwäge, was Engelmann (Bot. Ztg. 1884, pag. 441) rücksichtlich des Verhältnisses ärobiontischer Bacterien elwiesen hat. ${ }^{3}$ )

1) Vergl. Morphologie und Biologie der Pilze von A. De Bary, pag. 500.

2) Es ist auch nach Frank bei Lecanora pallida und anderen Flechten bekannt, dass die flechtenbewohnenden Algen, ohne anscheinend dabei abzusterben, den Chlorophyllgehalt grösstentheils oder ganz verlieren. De Bary, pag. 431. Gloeocapsa kommt als Gonidie in der Flechte Synalissa symphorea Nyl. vor.

3) Vergl. auch Pfeffer. Verh, d. deutschen bot. Gesellschaft I. J. G. pag. 531. 
Engelmann hat experimental die Annäherung gewisser Bacterien, das Hinbewegen derselben gegen Sauerstoff im Lichte ausscheidender Algen beobachtet. Der von mir oben geschilderte Befund zeigt nun, dass diese auf das Sauerstoffbedürfniss mancher Bacterien gegrŭndete Beziehung derselben zu Algen auch in der Natur zum Ausdruck kommt, wenn sich Bacterien mit Algen associeren. Dass sich also sanerstoffbedürftige Bacterien gewissen Algen nähern und mit denselben in Gemeinschaft zu günstiger Entwickelung gelangen. Da anderseits die Alge nicht abstirbt, sondern im Bacterienlager weiter wächst, so ist hier ein ähnliches Verhältniss anzunehmen, wio es zwischen Algen und flechtenbildenden Pilzen besteht. Die Alge wird von der Bacterie nicht parasitisch überfallen, sondern es besteht vielmehr zwischen beiden Organismen ein Mutualismus, welcher die günstige Entwickelung beider Organismen gestattet.

Da ich eine grössere Menge von diesem beachtungswerthen Gebilde theils getrocknet, theils in Alkohol aufbewahrte, bin ich gerne bereit, Forschern, welche weitere Untersuchungen vornehmen wollen, Proben davon auf Verlangen mitzutheilen.

Brünn, im April 1887.

\title{
Nochmals Utricularia brevicormis.
}

\author{
Von I. Čelakovský.
}

(Schluss.)

Prof. Ascherson war so gütig, mir die Originalbeschreibung Brückner's aus dem mir nicht zur Verfügung stehenden obcitirten Werke zu excerpiren, welche ziemlich kurz also lautet:

"Utricularia macroptera G. Brückn. Grabow im weissen Moor (Schm.) Ludwigshut bei der Kreuzbrücke? (Betcke). $U$. nectario obtuso, labio superiori integro, palato duplo longiori, foliis tripartitodichotomis, laciniis lineari-capillaribus, aequilongis, verrucoso-scabriusculis, subampulliferis. Fl. dan. tab. 128 teste $\mathrm{D} \theta$ th. in litt. Differt ab $U$. intermedia: floribus dimidio fere minoribus et nectario obtuso, - ab $U$. minore: labio superiore palato duplo vel triplo longiore et foliorum laciniis lineari-capillaribus subaequilongis nec linearibus, planis, pinnatifidis, pinnis alternis, brevibus, apice bifidis, acutis."

Wenn wir zunächst die Diagnose ohne Rücksicht auf das ohnehin keine sichere Auskunft gebende Herbar des Autors ins Auge fassen, so erhalten wir den Eindruck, dass es sich um eine zunächst mit $U$. intermedia verwandte Art handelt, die von $U$. minor durch mehrere deutliche Merkmale getrennt wird. Unter diesen ist zunächst die den Gaumen um das doppelte oder dreifache übertreffende Oberlippe der Corolle (daher wohl auch der Name macroptera), die allerdings bei $U$. intermedia und ochroleuca vorkommt, während sio 